\title{
Direct Antiglobulin Reaction in ABO-Haemolytic Disease of the Newborn
}

\author{
E. L. ROMANO, N. C. HUGHES-JONES, P. L MOLLISON
}

British Medical fournal, 1973, 1, 524-526

\section{Summary}

The minimum number of IgG anti-A (or anti-B) molecules detectable on $A$ or $B$ red cells by the antiglobulin reaction was found to be the same-that is, about 150 molecules per red cell-with newborn as with adult cells. Furthermore, the ratio of anti-IgG bound to IgG anti-A (or anti-B) molecules was the same whether the anti-A (or anti-B) molecules were present on newborn or on adult cells and was similar to that found for anti-IgG bound to IgG anti-Rh.

In 15 infants (11 group A, 4 group B) with haemolytic disease of the newborn due to ABO-incompatibility the amount of anti-A or anti-B on the red cells ranged from 0.25 to $3.5 \mu \mathrm{g}$ antibody per $\mathrm{ml}$ red cells, corresponding to $90-1,320$ antibody molecules per cell; only five infants had more than $0.55 \mu \mathrm{g}$ antibody per $\mathrm{ml}$ of red cells. These amounts are far smaller than those found in most moderate or severe cases of $\mathbf{R h}$ haemolytic disease.

It is concluded that the weak direct antiglobulin reactions observed in ABO-haemolytic disease are due simply to the fact that the number of anti-A (or anti-B) molecules on the infant's red cells is at the lower limit of sensitivity of the test. Since ABO-haemolytic disease can be quite a severe process it seems probable that IgG anti-A and anti-B molecules are more effective than anti-Rh molecules in bringing about red cell destruction.

\section{Introduction}

Even in moderately severe ABO-haemolytic disease of the newborn the infant's washed red cells give either a weakly positive or a negative direct antiglobulin reaction when routine techniques are used (Crawford et al., 1953). Although more sensitive techniques such as the "spin Coombs" may consistently give positive reactions even in mildly affected infants (Rosenfield, 1955), this finding only stresses that the antiglobulin reactions are much weaker than those observed in $\mathrm{Rh}$-haemolytic disease.

There seem to be several possible explanations for the finding of weak direct antiglobulin reactions in ABOhaemolytic disease; the amount of antibody on the circulating red cells may, in fact, be very small; most of the antibody may come off the red cells on washing; the $A$ and $B$ antigen sites on the red cells of newborn infants may be situated further from the cell surface than corresponding sites on adult cells, so that the anti-A and anti-B molecules become less accessible to antiglobulin serum after attachment to the sites; or there may be other steric effects which make cross-linking of antiglobulin molecules more difficult.

The questions posed above have been only partly answered by published work, mainly because no quantitative experi-

M.R.C. Experimental Haematology Unit, St. Mary's Hospital Medical School, London W.2

E. L. ROMANO, M.D., M.sc., Research Fellow from the Instituto Venezolano de Investigaciones Cientificas, Caracas

N.C. HUGHES-IONES, D.M., PH.D., Reader in Experimental Haematology P. L. MOLLISON, F.R.C.PATH., F.R.S., Professor of Haematology ments with labelled antisera have been undertaken. It seemed that if quantitative experiments using both labelled anti- $A$ and labelled antiglobulin serum were carried out some of the confusion which surrounds this subject might be dissipated.

\section{Subjects and Methods}

Normal Newborn Infants.-Cord blood was obtained at the time of delivery and mixed with acid-citrate-dextrose solution (ACD) (4 parts blood to 1 part $A C D$ ) and kept at $4^{\circ} \mathrm{C}$ for up to seven days before being tested. The red cells were washed four times in saline before being used. Only red cell samples which were agglutinated by an extract of Dolichos biflorus were used.

Infants with ABO-haemolytic Disease.-The diagnosis was made by the finding in a full-term $A$ or $B$ infant born to an $O$ mother of a serum bilirubin concentration of $10 \mathrm{mg} / 100 \mathrm{ml}$ or more on the second or third day of life; in eight cases the concentration reached $18 \mathrm{mg} / 100 \mathrm{ml}$ or more; seven of these infants and one other were treated by exchange transfusion. In most cases microspherocytes were prominent in films of peripheral blood. There were 4 group $B$ and 11 group A infants; the red cells of the latter were tested with an extract of $D$. biflorus; seven samples were strongly agglutinated, two were weakly agglutinated, and two were not agglutinated at all. In all cases eluates were prepared from the infant's red cells by the method of Landsteiner and Miller (1925) and tested against $A_{1}$ or $B$ red cells by the indirect antiglobulin method.

Normal Adults.-Blood was mixed with ACD and stored at $4^{\circ} \mathrm{C}$ for up to seven days. Only samples which were agglutinated by an extract of $D$. biflorus were used. The cells were washed four times in normal saline before being tested.

IgG Anti-A.-Using standard diethylaminoethyl-cellulose chromatography IgG anti-A (free from IgM) was prepared from plasma obtained from a group $O$ subject who had received injections of purified human $A$ substance (kindly supplied by Professor Winifred M. Watkins). The IgG fraction was labelled with ${ }^{125}$ I by the iodine monochloride method (McFarlane, 1958). The specific activity of the preparation was determined from the protein concentration using FolinCiocalteu's reagent. The concentration of IgG anti-A was $84 \mu \mathrm{g} / \mathrm{ml}$ and the indirect antiglobulin titre against $A_{1}$ red cells was 8,000 .

Radioiodine-labelled Anti-IgG Serum.-Horse antihuman IgG was prepared by the method of Avrameas and Ternynck (1969). The product was labelled with either ${ }^{131} I$ or ${ }^{125} I$ as convenient.

Uptake of IgG Anti-A on to Cord and Adult A Red Cells. - The number of antigen sites on $A_{1}$ cord or adult cells was estimated using ${ }^{125} \mathrm{I}$-labelled IgG anti-A. The minimum number of anti-A molecules detectable with the antiglobulin test on cord and adult $A$ cells was determined as follows. A fixed number (approximately $2 \times 10^{8}$ ) of $A_{1}$ adult or cord red cells were incubated at $37^{\circ} \mathrm{C}$ for 90 minutes with serial dilution of ${ }^{125} \mathrm{I}$-labelled anti-A at a ratio of 1 volume red cells to 4 volumes anti-A. Group $O$ red cells were used as a control. The cells were washed four times with ice-cold saline and the uptake of ${ }^{125} \mathrm{I}$ was determined within 30 minutes. The same samples of red cells were tested for agglutination by optimally diluted rabbit antihuman IgG both macroscopically (using a tile) and microscopically after centrifugation for 
10 seconds at low speeds. The results were calculated from the specific activity of the preparation, the red cell count, and the packed cell volume of the suspension, and, assuming the molecular weight of IgG to be 160,000 , were expressed either as molecules of anti-A per red cell or as $\mu \mathrm{g}$ of anti-A per $\mathrm{ml}$ of red cells. The ratios of anti-IgG molecules to IgG anti-A molecules on infant and adult $A$ red cells and the number of anti$A$ or anti-B molecules on the red cells of infants affected with ABO-haemolytic disease were determined by the method of Rochna and Hughes-Jones (1965). In order to discover how much anti-A was eluted from cord red cells on washing, the red cells of two infants with ABO-haemolytic disease were washed four times in saline and the wash solutions were saved, concentrated, and tested by the indirect antiglobulin method. In addition, experiments were done with normal A red cells sensitized in vitro with ${ }^{125}$ I-labelled IgG anti-A; the supernatant solutions from four consecutive washes were pooled and counted.

\section{Results}

Maximum Number of Anti-A Molecules taken up by Cord and Adult $A_{1}$ Cells.-Two A cord samples and two $A_{1}$ adult samples were tested; the average number of antigen sites, corresponding to the maximum number of anti-A molecules taken up, was found to be approximately $0.3 \times 10^{6}$ and $1.2^{\circ} \times 10^{8}$ per cell respectively. These estimates are of the same order as those previously reported (Economidou et al., 1967).

Minimum Number of IgG Anti-A Molecules detectable on Cells using Anti-IgG Serum.-For both adult and cord $A_{1}$ red cells the least number of anti-A molecules which could be detected by the indirect antiglobulin method was approximately 150 per cell (table I). The reactions of adult and cord red cells coated with similar numbers of anti-A molecules were indistinguishable.

TABLE I-Reactions with an Anti-IgG Serum of Normal Adult and Cord $A_{1}$ Red Cells coated In Vitro with Similar Numbers of IgG Anti-A Molecules

\begin{tabular}{c|c|c|c}
\hline \multicolumn{2}{c|}{ Adult Red Cells } & \multicolumn{2}{c}{ Cord Red Cells } \\
\hline $\begin{array}{c}\text { No. of IgG } \\
\text { Anti-A } \\
\text { Molecules/Cell }\end{array}$ & $\begin{array}{c}\text { Reactions } \\
\text { with Antiglobulin } \\
\text { Serum }\end{array}$ & $\begin{array}{c}\text { No. of IgG } \\
\text { Anti-A } \\
\text { Molecules/Cell }\end{array}$ & $\begin{array}{c}\text { Reactions } \\
\text { with Antiglobulin } \\
\text { Serum }\end{array}$ \\
\hline 2,500 & ++ & 2,140 & ++ \\
970 & ++ & 1,060 & ++ \\
520 & + & 490 & + \\
214 & + & 161 & + \\
145 & Trace & - & Trace \\
128 & - & & \\
\hline
\end{tabular}

The reactions with an antiglobulin serum are given as ++ or + to indicate degree agglutination; "trace" indicates that only a dubious reaction was present on

Ratio of Antiglobulin: Anti-A Molecules on Cord and Adult $A_{1}$ Red Cells.-Cord and adult red cells were coated with approximately $10 \mu \mathrm{g}$ of ${ }^{225} \mathrm{I}$-labelled IgG anti-A per $\mathrm{ml}$ of cells and incubated with decreasing concentrations of ${ }^{131} \mathrm{I}$ labelled horse antihuman IgG at an initial concentration of about $15 \mu \mathrm{g}$ of anti-IgG per $\mathrm{ml}$. The extent of the reaction between anti-IgG and IgG anti-A on cord and adult red cells was about the same, the maximum ratio of anti-IgG to IgG molecules being 1.8 to 2.0 . In a control experiment in which D-positive red cells coated with anti-D were used a similar ratio was observed.

Number of Anti-A and Anti-B Molecules on Red Cells in Cases of ABO-haemolytic Disease.-The amount of anti-A or anti-B on the red cells ranged from 0.25 to $3.5 \mu \mathrm{g} / \mathrm{ml}$ (table II); these amounts correspond to 90 to 1,320 molecules of antibody per cell. The direct antiglobulin test was positive in 11 cases when read macroscopically and positive in 1 further case when read microscopically. In this last case and in the
TABLB II-Cases of ABO-haemolytic Disease

\begin{tabular}{|c|c|c|c|c|c|c|c|}
\hline \multirow{3}{*}{$\begin{array}{l}\text { Case } \\
\text { No. }\end{array}$} & \multirow{3}{*}{$\begin{array}{l}\text { Blood } \\
\text { Group }\end{array}$} & \multicolumn{4}{|c|}{ Infants } & \multirow{2}{*}{\multicolumn{2}{|c|}{$\begin{array}{c}\text { Mothers } \\
\text { (All Group O) } \\
\text { Indirect Anti- } \\
\text { globulin Test* } \\
\text { (Anti-A or Anti-B) }\end{array}$}} \\
\hline & & \multicolumn{2}{|c|}{$\begin{array}{l}\text { Maximum Re- } \\
\text { corded Plasma } \\
\text { Bilirubin } \\
\text { Concentration }\end{array}$} & \multicolumn{2}{|c|}{$\begin{array}{c}\text { Direct } \\
\text { Antiglobulin } \\
\text { Test }\end{array}$} & & \\
\hline & & $\underset{\mathrm{ml}}{\mathrm{mg} / 100}$ & $\begin{array}{c}\text { Time } \\
\text { After } \\
\text { Birth } \\
\text { (Hours) }\end{array}$ & $\begin{array}{l}\text { Routine } \\
\text { Method }\end{array}$ & $\begin{array}{l}\mu g \text { Anti- } \\
\text { body per } \\
\text { ml Red } \\
\text { Cells }\end{array}$ & Titre & $\begin{array}{c}\text { Time } \\
\text { After } \\
\text { Delivery } \\
\text { (Days) }\end{array}$ \\
\hline $\begin{array}{l}1 \\
2 \\
3\end{array}$ & $\begin{array}{l}\mathbf{A} \\
\mathbf{A} \\
\mathbf{B}\end{array}$ & $\begin{array}{l}19 \cdot 4 \\
27 \cdot 0 \\
18 \cdot 0\end{array}$ & $\begin{array}{l}48 \\
72 \\
60\end{array}$ & $\begin{array}{l}\text { Neg. } \\
\text { Neg. } \\
+\end{array}$ & $\begin{array}{l}0.25 \\
0.30 \\
0.35\end{array}$ & $\begin{array}{r}32 \\
16 \\
512\end{array}$ & $\begin{array}{l}1 \\
3 \\
4\end{array}$ \\
\hline $\begin{array}{r}4 \\
5 \\
6 \\
7 \\
8 \\
9 \\
10 \\
11 \\
12 \\
13 \\
14 \\
15\end{array}$ & $\begin{array}{l}\mathbf{A} \\
\mathbf{A} \\
\mathbf{B} \\
\mathbf{A} \\
\mathbf{A} \\
\mathbf{B} \\
\mathbf{A} \\
\mathbf{B} \\
\mathbf{A} \\
\mathbf{A} \\
\mathbf{A} \\
\mathbf{A}\end{array}$ & $\begin{array}{l}14 \cdot 3 \\
12 \cdot 5 \\
11 \cdot 0 \\
27 \cdot 0 \\
10 \cdot 1 \\
22 \cdot 6 \\
13 \cdot 6 \\
18 \cdot 0 \\
14 \cdot 0 \\
20 \cdot 0 \\
24 \cdot 0^{+}\end{array}$ & $\begin{array}{l}60 \\
24 \\
48 \\
24 \\
48 \\
48 \\
24 \\
24 \\
24 \\
72 \\
72\end{array}$ & $\begin{array}{c}+ \\
\text { Neg. } \\
+ \\
+ \\
+ \\
+ \\
+ \\
+ \\
+ \\
++ \\
++ \\
++\end{array}$ & $\begin{array}{l}0.35 \\
0.35 \\
0.40 \\
0.40 \\
0.45 \\
0.55 \\
0.55 \\
1 \cdot 10 \\
1.40 \\
1.85 \\
2.25 \\
3.50\end{array}$ & $\begin{array}{l}1,000 \\
128 \\
4,000 \\
2,000 \\
1,000 \\
256 \\
1,000 \\
2,000 \\
512 \\
1,000 \\
1,000 \\
2,000\end{array}$ & $\begin{array}{c}-1 \\
2 \\
7 \text { weeks } \\
8 \\
4 \text { weeks } \\
2 \\
6 \\
7 \\
1 \\
3 \\
1 \\
3\end{array}$ \\
\hline
\end{tabular}

Anti-IgG.

Cord bilirubin concentration $5.8 \mathrm{mg} / 100 \mathrm{ml}$; no later estimates.

three cases in which the test gave negative readings the amount of anti-A or anti-B on the red cells was always less than $0.4 \mu \mathrm{g} / \mathrm{ml}$. In all 14 cases in which an eluate was prepared from the infant's red cells the expected antibody (antiA or anti-B) was shown to be present.

Elution of Anti-A from A Red Cells during washing.Only traces of anti-A were detected in the wash solutions obtained from the red cells of two infants with haemolytic disease due to anti-A. Similarly, in quantitative experiments with normal A cells coated in vitro with ${ }^{125}$ I-labelled IgG antiA a maximum of $20 \%$ of antibody was recovered from four consecutive washes.

\section{Discussion}

The present results show that the minimum number of IgG anti-A (or anti-B) molecules detectable on red cells by the antiglobulin test is about 150 per cell for both cord and adult red cells. The number is about the same as that previously reported (Dupuy et al., 1964; Hughes-Jones et al., 1964) for the detection of IgG anti-Rh by the antiglobulin test. Since evidence was obtained that relatively little IgG anti-A is lost from "coated" red cells on washing it must be concluded that the weak positive direct antiglobulin test reaction, which is characteristic of ABO-haemolytic disease, indicates that in this disease relatively few antibody molecules are attached to the circulating red cells. In the present series of $\mathbf{1 5}$ cases the amount of anti-A or anti-B found on the cells was estimated to be between 0.25 and $3.5 \mu \mathrm{g} / \mathrm{ml}$; the median value was $0.45 \mu \mathrm{g} / \mathrm{ml}$, and only five values were above 0.55 $\mu \mathrm{g} / \mathrm{ml}$. At levels of approximately $1 \mu \mathrm{g} / \mathrm{ml}$ the estimates carry a considerable error because this amount of antibody on the cells is almost of the same order as the amount of non-specific ${ }^{125}$ I-labelled IgG bound to the cells. The error is unlikely to be greater than $\pm 50 \%$, however, so that in any case the amount of specific antibody (anti-A or anti-B) bound in a typical case is unlikely to be greater than about $1 \mu \mathrm{g} / \mathrm{ml}$. This degree of coating is much less than that usually found in $\mathbf{R h}-$ haemolytic disease, in which the amount in one series of cases (Hughes-Jones et al., 1967) was found to vary between 0.4 and $18 \mathrm{\mu g} / \mathrm{ml}$, depending on severity.

In $\mathrm{Rh}$-haemolytic disease the amount of antibody on the infant's red cells expressed as $\mu \mathrm{g} / \mathrm{ml}$ of cells is very approximately the same as the concentration of anti-Rh in the mother's plasma in $\mu \mathrm{g} / \mathrm{ml}$ of plasma (Hughes-Jones et al., 1971). On the other hand, in ABO-haemolytic disease the amount of antibody per $\mathrm{ml}$ on the infant's red cells may be as 
little as one-fortieth of the concentration of the corresponding antibody in the mother's plasma. For example, in the present series the median value of antibody on the infant's red cells was $0.45 \mu \mathrm{g} / \mathrm{ml}$, whereas the median value of IgG anti-A or anti-B in the mother's plasma was probably about $20 \mu \mathrm{g} / \mathrm{ml}$ (taking the median indirect antiglobulin titre in the series as 1,000 and assuming that, as with anti- $R \mathrm{~h}$, an indirect antiglobulin titre of 1 corresponds to about $0.02 \mu \mathrm{g}$ of antibody per $\mathrm{ml}$ ). The smaller amounts of anti-A and anti-B on the infant's red cells were presumably due mainly to the competing effect of $\mathbf{A}$ and $\mathbf{B}$ substances widely scattered throughout the body tissues and secretions (Tovey, 1945).

The fact that weakly positive direct antiglobulin reactions are associated with a definite haemolytic syndrome when anti$A$ and anti-B are concerned, whereas a weakly positive direct antiglobulin reaction due to anti-Rh may be associated with no increase in red cell destruction whatever (Mollison, 1951), indicates that IgG anti-A and anti-B are relatively more effective than anti-Rh in producing red cell destruction. One possible explanation of the difference would be that IgG anti-A and anti-B, unlike anti-Rh, bind complement. On the other hand, if $\mathbf{A}$ and $\mathbf{B}$ sites are distributed at random on the red cell surface it would be expected that a minimum of 800 molecules of antibody would have to be present on each red cell before there was an even chance that two antibody molecules would occupy adjacent sites and so activate complement (Humphrey and Dourmashkin, 1965). This reasoning would not apply if A and B antigen sites, when combined with their specific antibody, were present in clusters in the red cell surface as, in fact, they may be (see below).

Some observations which appear to contradict the present findings of only small amounts of antibody on the red cells of infants with haemolytic disease of the new born must be briefly discussed. Voak and Bowley (1969) reported that eluates from the red cells in infants with $A B O-h a e m o l y t i c$ disease might give strong indirect antiglobulin reactions with adult $A_{1}$ red cells, although the direct antiglobulin reaction on the infant's red cells was only weakly positive or even negative. This observation might seem to indicate that the infant's red cells were coated with large amounts of antibody. In a latter paper, however (Voak and Williams, 1971), it was pointed out that the elution procedure resulted in a considerable concentration of antibody, so that the finding does not necessarily indicate that' there is a substantial amount of antibody on each cell. If one considers some actual quantities the degree of concentration involved in elution can be better appreciated. Suppose, for example, that antibody is eluted from $0.5 \mathrm{ml}$ of red cells coated with $0.5 \mu \mathrm{g} / \mathrm{ml}$ of anti-A and $60 \%$ of the antibody is removed during elution; the total amount of antibody eluted would then be $0.15 \mu \mathrm{g}$. Now, suppose that the eluate is incubated with $0.1 \mathrm{ml}$ of a $5 \%$ suspension of red cells and that $80 \%$ of the antibody is taken up by the cells; there is then $0.12 \mu \mathrm{g}$ on $0.005 \mathrm{ml}$ of cells or $24 \mu \mathrm{g} / \mathrm{ml}$, sufficient to give a very strong antiglobulin reaction.

Voak and Williams (1971), using electron microscopy and ferritin-labelled IgG anti-A and anti-B, found evidence of clustering of antigen sites on both adult and infant red cells. They suggested that the reason for the relatively weak antiglobulin reactions of cord A cells might be the relatively greater distance between the A sites on the infant cells compared with the shorter distance on adult $A_{1}$ cells, making cross-linking by anti-IgG molecules difficult. Even on newborn red cells, however, the number of sites is about 10 times greater than the number of $\mathrm{Rh}(\mathrm{D})$ sites, so that the distance between $D$ sites must be much greater than that between $A$ sites. Moreover, the present observations indicate that the ratio of anti-IgG molecules to anti-A molecules is, in fact, the same with adult and infant $A_{1}$ cells and, incidentally, is the same as that observed with anti-IgG and anti-Rh on Rh-positive red cells.

In the present series, as in the series reported by Gerlini et al. (1968), the red cells of some group A infants with haemolytic disease due to anti-A were not agglutinated by an extract of $D$. biflorus, suggesting that contrary to present belief $A_{2}$ infants as well as $A_{1}$ infants may be affected. On theoretical grounds there does not seem to be any reason why $A_{2}$ infants should be spared. Even if the number of $A$ sites on the red cells of newborn infants who are genetically $A_{2}$ is as low as 50,000 , A molecules (red cell antigen sites) would be in considerable excess over anti-A molecules in the plasma, so that the number of antibody molecules taken up by $\mathrm{A}_{2}$ cells should be scarcely less than that taken up by $A_{1}$ cells.

We are grateful to the following people who kindly arranged to have blood samples sent to us from infants with ABO-haemolytic disease: Dr. S. Ardeman, Mrs. Sheila Haddad, and Drs. W. J. Jenkins, J. Murray, F. Stratton, G. H. Tovey, L. A. D. Tovey, and W. Walker. We are also grateful to Mrs. Brigitte Gardner and Mrs. Marion Newlands for technical help.

\section{References} Avrameas, S., and Ternynck, T. (1969). Immunochemistry, 6, 53. Dupuy, Mary E., Elliot, Margaret, and Masouredis, S. P. (1964). Vox Sanguinis, 9, 40.

Economidou, Joanna, Hughes-Jones, N. C., and Gardner, Brigitte (1967) Vox Sanguinis, 12, 321 .

Gerlini, G., Ottaviano, S., Sbraccia, C., and Carapella, E. (1968). Haematologica, 53, Suppl., p. 1019

Hughes-Jones, N. C., Hughes, M. I. J., and Walker, W. (1967). Vox Sanguinis, 12, 279 .

Hughes-Jones, N. C., Ellis, M. Ivona J., and Walker, W. (1971). Vox Sanguinis, 21, 135

Hughes-Jones, N. C., Polley, Margaret J., Telford, R., Gardner, Brigitte, and Kleinschmidt, G. (1964). Vox Sanguinis, 9, 385.

Humphrey, J. H., and Dourmashkin, R. R. (1965). In Ciba Foundation Symposium: Complement, ed. G. E. W. Wolstenholme and Julie Knight, p. 175. London, Churchill.

Landsteiner, K., and Miller, C. P. (1925). Fournal of Experimental Medicine,

42, 853.
McFarlane, A. S. (1958). Nature, 182, 53.

McFarlane, A. S. (1958). Nature, 182, 53.
Mollison, P. L. (1951). Blood Transfusion in Clinical Medicine, p. 382. Oxford, Blackwell Scientific.

Rochna, Erna, and Hughes-Jones, N. C. (1965). Vox Sanguinis, 10, 675.

Rosenfield, R. E. (1955). Blood, 10, 17.

Tovey, G. H. (1945). Fournal of Pathology and Bacteriology, 57, 295.

Voak, D., and Bowley, C. C. (1969). Vox Sanguinis, 17, 321.

Voak, D., and Williams, M. A. (1971). British fournal of Haematology, 20, 9. 